Verano/Verão 2018

\title{
Kant and Fichte on Belief and Knowledge
}

Halla Kim

\section{OpenEdition}

\section{Journals}

Electronic version

URL: http://journals.openedition.org/ref/895

DOI: $10.4000 /$ ref.895

ISSN: 2258-014X

\section{Publisher}

EuroPhilosophie Editions

\section{Electronic reference}

Halla Kim, «Kant and Fichte on Belief and Knowledge », Revista de Estud(i)os sobre Fichte [Online], 17| 2018, Online since 01 December 2018, connection on 10 December 2020. URL : http:// journals.openedition.org/ref/895; DOI : https://doi.org/10.4000/ref.895

This text was automatically generated on 10 December 2020 .

(c) EuroPhilosophie 


\title{
Kant and Fichte on Belief and Knowledge
}

\author{
Halla Kim
}

One of the most venerable distinctions in philosophy is the one between knowledge (episteme) and belief (doxa). Knowledge is one of the noblest/perennial goals of human activities, and it has been typically associated with genuine or scientific cognition that can provide truth whereas belief has been thought to present mere appearances or subjective opinion, usually founded on sense perceptions. In this paper, I will argue that for both Kant and Fichte, this standard view is mistaken, and, as opposed to this mainstream view, both of them present beliefs (Glaube) as more important than knowledge. In his lectures on logic, Reflexionen and published works, Kant presents knowledge (Wissen), opinion (Meinung) and belief (Glaube) as our three main modes of "holding-to-be-true" (Fürwahrhalten). Even though Kant admits that knowledge is prior, and superior, to belief as well as opinion in their purely epistemic dimension, Kant nevertheless ends up holding that belief in the more significant sense of a 'postulate,' is more important than knowledge. I will also argue that this is the fundamental point of his well-known doctrine of the primacy of practical reason over theoretical reason. The standard view is also challenged by Fichte's thoroughgoing transformation of our epistemic enterprise or rather its "reversal". For Fichte, belief (Glaube) is prior to knowledge (Wissen) (GA I/6, 253). Belief has something to do with "a resolution of the will" to admit the validity of knowledge. In this respect, it indicates a "firmness of my confidence," that is "reason's firm and unshakable adherence to a principle" (VM 104). In this sense, it refers to our deepest commitment to and reaffirmation of our nature as pure activity (Tathandlung). In other words, belief here is equated with the practical act of the self that expresses its true nature as Tathandlung. This is why belief is clearly different from discursive or propositional knowledge. In the course of the paper, I will also show that Kant and Fichte seem to argue for their view in a different way. For Kant, the superiority of belief is presented as part of his architectonic concern, i.e., as an answer to the question "what may I hope" in the context of his elaborate theory of postulates. For Fichte, the doctrine is presented as part of his transcendental- 
ontological project of securing the reality of the self and the world from our moral vocation. Or so I shall argue.

\section{Kant}

2 Since the days of Plato, philosophers have often claimed that knowledge has a kind of privileged status that a mere belief lacks. For Kant, a true science (Wissenschaft) must carry universality and necessity where each of its components expresses knowledge and forms a part of a systematic whole. Thus, for Kant, knowledge is universal and necessary. Kant's transcendental philosophy crucially involves justification of a priori synthetic knowledge. In particular, in his epistemological project, knowledge comes from the joint work of the sensibility and the understanding. The sensibility provides the materials but it is the understanding that provides the a priori forms that can organize and process the materials. But the forms are not derived from without. It is the transcendental subject that is the source of the forms and that can serve as the lawgiver of nature.

3 In practical philosophy, the ethical subject gives law to herself as well. So the ethical subject is a lawgiver. But the two laws that the cognitive subject and the practical subject give are of fundamentally different types. The laws of nature are deterministic causal laws, but the laws of actions are the laws of freedom. The human knowledge is confined to the deterministic natural world but the ethical subject is able to act freely beyond nature. Thus, there arises a discrepancy between nature and freedom. In this way, we can see that there emerges a cleavage between theoretical reason and practical reason in Kant's project. This is part of the point that is addressed in his question, "what may I hope?" in the Canon of the Critique of Pure Reason (B 832 - 847). ${ }^{1}$

4 But how does Kant bridge the gap between nature and freedom? How exactly does Kant find that the physical world can "harmonize with" morality in this way? Is this accomplished by way of divine agency or is this harmony a human task? Kant typically views judgments as intentional actions (Handlungen) (A69/B94) engaging with the truth-value of propositions. Thus, for him, a judgment is the basic unit of all our rational activities. For this reason, any propositional attitude is an instance of "holding-to-be-true" (das Fürwahrhalten) (A820/B848) (9: 66), constituting a determinate way in which the rational cognitive subject produces an assertable judgment. (Hanna 2013) Holding-to-be-true, in turn, has three basic kinds: (i) "opining" (Meinen), (ii) "scientific knowing" (Wissen), and (iii) "believing" (Glauben) (A820-831/B848-859).

Opining is an epistemic propositional attitude that falls short of "conviction" ( Überzeugung), i.e., objective sufficiency for the rational/judging subject, and also falls short of "persuasion" (Überredung), i.e., mere subjective sufficiency for the rational/ judging subject. Hence opining includes such subjectively and objectively unconvinced attitudes as entertaining a proposition, fiction, supposition, etc.

Believing, by contrast, includes subjective sufficiency or persuasion for the rational/ judging subject, but also, on its own, falls short of conviction, which includes both subjective sufficiency or persuasion and also objective sufficiency, which itself, in turn, necessarily includes truth in such a way as to rule out any sort of accidental connection between epistemic believing and truth, i.e., cognitive-semantic luck, and for that reason is also called "certainty" (Gewissheit). Finally, then, scientific knowing is 
perfected epistemic believing that has achieved conviction, i.e., objective sufficiency or certainty.

7 Further, Kant divides believing or Glauben into four distinct doxic sub-kinds: (i) epistemic (or scientific-knowing-oriented) belief, (ii) transcendental metaphysical belief, (iii) "pragmatic" (or instrumental) belief, and finally (iv) "moral" (or ethical) belief. (Hanna 2013) ${ }^{2}$ For Kant moral belief is a propositional attitude that is epistemically objectively insufficient. But it can be fully and sufficiently justified in practical terms. For it is backed up by the Categorical Imperative and the system of duties it gives rise to, among them the duty of promoting summum bonum (the highest good). A moral belief is such that "it is absolutely necessary that something must happen, namely that I fulfill the moral law in all points" (A828/B856). This is why the Kantian moral belief is different from transcendent metaphysical belief, which is unstable because it is bound to generate rationally unavoidable dialectical fallacies and contradictions

8 Despite the many senses of believing or Glauben, for Kant, the most important kind of believing is moral belief. A belief in this sense expresses a theoretical proposition that cannot be proven on theoretical grounds alone (CPrR 5: 122-134). It is, however, inextricably bound up with morality and in this respect importantly supported by the latter. Further, even though it is not epistemically proved, i.e., scientifically verified, it is rational as it is bound up with morality. So, unlike an epistemic belief, it cannot be turned into knowledge.

9 Is belief in this practical sense compatible with knowledge? Kant clearly suggests that our knowledge concerns the natural world, i.e., the world of phenomena but belief in this sense is concerned with the supersensible world. In this respect, belief is not necessarily in conflict with knowledge. More importantly for our purpose, Kant suggests that belief in this sense is superior to knowledge. But why is this the case?

In the aftermath of the pantheism controversy that was all the rage in Germany in late 1770's, Kant was also greatly alarmed by Friedrich Jacobi's insistence on the need to rethink the presumed worth of reason. Kant apparently conceived it his mission to sustain the Aufklärung in the face of Jacobi's relentless attack. His doctrine of rational faith, already worked out in the "Canon" of the first edition of the Critique, appeared to silence all of Jacobi's doubts. ${ }^{3}$ In this regard, he was very sympathetic to Moses Mendelssohn's critique of irrationalism inherent in Jacobi's religiously oriented vision of morality. The latter's attempt was nothing else but an epitome of Schwärmerei. Indeed, a Schwärmer is a mystic who believes that God is known intuitively through a special sense organ. Blindly relying on the mystical perception of the divine, such a fanatic thinks that one should subordinate all of one's thoughts and actions to a single purpose. Private ideas are bound to dominate over the sense of objective reality in fanaticism. ${ }^{4}$ Jabobi's fanaticism leads to deception and manipulation. Since Jacobi cannot make use of reason or rational argument he deceives people into believing by inducing fear of reason and enlightenment. In short, Schwärmerei is madness (Verrü ckung). It also leads to a conception of God that is despotic. We cannot use reason to evaluate the morality of God's dictates. A threat of religious oppression immediately looming.

11 On the other hand, throughout his career, Kant is not only cautiously opposed to any form of empiricist skepticism which completely discounts knowledge but also he is carefully on guard against all forms of dogmatism. The metaphysical beliefs of 
dogmatism should not encroach on the realm of knowledge. Thus, he makes every effort to put a limit on all attempts to give objective reality to the ideas of God, freedom and the immortality of the soul. These are merely thinkable but not knowable. Thus, he was not able to side with Mendelssohn's ultra-rationalist trust in the unlimited power of reason. In particular, to Kant's eyes, the traditional rationalist attempt at proving God, and immortality of the soul are no different from the ages-old dogmatic assertions without any foundations.

Kant's solution to the conceptual impasse between Jacobi's enthusiasm and Mendelssohn's hyper-rationalism is the doctrine of rational belief. We have beliefs that are rational yet not scientifically proven. Furthermore, these are beliefs that can serve as the bridge between nature and freedom. For, even though these beliefs do not produce knowledge of the sensible world, they concern the supersensible world and its inhabitants. Thus, in a famous passage in the B-edition Preface to the Critique of Pure Reason he says that "I had to deny knowledge (Wissen) in order to make room for faith (Glauben)" (Bxxx). As opposed to the super-rationalist attempt, he hopes to restrict the scope of epistemic believing and scientific knowing, by means of his Critical epistemology and transcendental idealist metaphysics, in order to make room for fully and sufficiently practically justified moral beliefs or believing. On the other hand, pace fanaticism, he wishes to defend these beliefs as rationally anchored in our moral outlook on the world. In this way, moral beliefs are shown to philosophically trump epistemic beliefs (including the best of current sciences) and also doctrinal beliefs (including the traditional transcendent metaphysics). This is known as Kant's doctrine of the primacy of the practical.

The rational but moral beliefs here concern what Kant calls "postulates of pure practical reason" (CPrR 5: 122-134), which most notably include the immortality of the soul and the existence of God. In Kant's ethics of belief, the soul's immortality and God's existence are something that we cannot possibly know scientifically, yet at the same time they specify certain morally obligatory ways of living one's life as a rational human agent. For Kant, postulates "give objective reality to the idea of speculative reason in general (by means of their reference to what is practical) and justify its holding concepts even the possibility of which it could not otherwise presume to affirm" (5:132). This is because, as theoretical propositions, "postulates are... then presuppositions having a necessarily practical reference," ... albeit "not one demonstrable as such, insofar as [they are] attached inseparably to an a priori unconditionally valid practical law" (5:122). The ideas of God and immortality are not conditions of the moral law but only conditions of the necessary object of a will determined by this law (ibid.). Thus we must assume or take them for granted as "the necessary conditions for observance of the precept [of the will]" (5:132). It is wellknown that Kant identifies three postulates for his ethical system: freedom, immortality and the existence of God (ibid.). Most importantly for our purpose, we have the rational need to postulate the existence of God as the one who has the power to bring virtue and happiness into harmony in that next life. This is the only way that fairness will be achieved in the universe with virtue and happiness harmonized. It is important to understand that Kant was not arguing that morality is invalid if God's existence is denied; rather, for Kant, the fact that something is a duty or obligation is sufficient reason to do it. The most fundamental move that Kant makes here is the claim that a reflection on our moral law requires belief in free will, God, and the immortality of the soul. Although we cannot have knowledge of these things, reflection 
on the moral law leads to an authenticated belief in them, which amounts to a kind of rational 'faith.' Nonetheless, Kant argues that the existence of God must be postulated if the ultimate task of morality, i.e., the highest good (summum bonum) as our overall happiness proportional to our virtue was to be carried out. Kant invokes the primacy of practical reason, so that the practical subject may accept the postulates of God, freedom and immortality "as a foreign possession handed over to it" (5:120). This is how Kant links nature and freedom, i.e., the realm of theoretical reason and that of practical reason. In this teleologically contrived scheme of things, Kant seems to suggest that the cognitive subject and the acting subject are one and the same because the principle that unifies the spheres of theoretical and practical reason is the assumption of a wise and benevolent God who has created a teleological world that coheres with morality.

Thus, in response to the question "What may I hope?" Kant answers that we human beings may hope that our souls are immortal and that there really is a God who designed the world in accordance with principles of justice. Indeed, this question, as far as its answer depends on claims regarding the consequences of moral righteousness and the existence of God, is "simultaneously practical and theoretical" (A805/B833) and it is answered by religion (AE 9:25). Kant's account of hope consequently connects his moral philosophy with his views on religion as well as knowledge. He emphasizes the rational potential of such hope, but he also makes clear that rational hope is intimately connected to religious faith, i.e., the belief in God for embodied beings such as us humans.

\section{Fichte}

Now I turn to Fichte's view of belief and knowledge. Despite his continued engagement with the venerable Kantian transcendental project in his Jena writings including the System of Ethics, Fichte clearly feels that it falls far short. In particular, he complains that Kant as well as his contemporaries have failed to ask what our power to act in the world consists in, suggesting that they have merely focused on an analysis of our power to represent the world. If you focus on the power of representations and its product alone, i.e., discursive knowledge, you cannot find your vocation in life. ${ }^{5}$ Indeed, as Fichte succinctly shows in Book I of the Vocation of Man, it only leads to a soulless universe of determinism. Discursive knowledge cannot explain our freedom and dignity. ${ }^{6}$ It is thus completely useless as a way of disclosing the dynamic reality itself. What is more, it also leads to solipsism. ${ }^{7}$ Theoretical reason, when dogmatically conceived in the manner of Spinozism, simply cannot explain freedom, the hallmark of our active nature. Fichte thus gives up dependence on realist approaches to knowledge. 8

In Book II of the same work, Fichte goes on to consider theoretical reason now conceived in the Kantian transcendental fashion, and finds that in it we are connected to the world only through our representations and the underlying power thereof. There must be something outside of our representations but we cannot make any progress if we are exclusively preoccupied with them. In other words, the theoretical but transcendental knowledge cannot prove anything outside of itself. Something other than purely cognitive and intellectual resources is needed in order to fully grasp and ground this reality. Thus, the Kantian transcendental idealism (at least without what 
Fichte later calls "belief" or "conviction") leads to skepticism. If idealism begins and ends in Kant's manner, i.e., with its transcendental-epistemological explanation of the conditions of experience,

you absolve me of all dependence by transforming me and everything around me on which I might be dependent into nothing. You do away with necessity by doing away with and annihilating all being (VM 60; GA I, 6: 247).

There is no being.... There are images... images which drift by, without there being anything by which they drift ... images which do not represent anything, without meaning and purpose.... All reality is transformed into a fabulous dream, without there being any life the dream is about... (VM 63-64; GA I, 6: 251)

Fichte then asks:

...what is that lies beyond all representations?" (ibid.)

18 He goes on to answer that there is "something which is more and higher than all knowledge and that contains the final purpose of knowledge within itself" (VM, 84; GA I, 6: 254). This something turns out to be morality. This revelation then ties us to the objective world (ibid). We now must renounce our dependence on mere knowledge and aim at morality. But how can this be?

For morality to be possible, Fichte points out, there must be within me "a drive to absolute independent self-activity" (VM 68; GA I, 6: 254)," which can ultimately serve as "the point where consciousness connects with reality" (VM 68; GA I, 6: 254). We are practical agents first and this means that we can go beyond mere representations because our consciousness is based on a drive to autonomy which is inseparably bound up with our self-consciousness. Furthermore, this consciousness of ourselves reveals itself as a feeling. ${ }^{10}$ It is this feeling that can give rise to the objective world only if it is endowed with an objective certainty. But this latter cannot be granted by any sort of logical-deductive knowledge. ${ }^{11}$ In fact, as the latter takes its departure from some grounds, it would end up as a necessary link in an infinite chain of causal nexus, as we have seen in VM I (VM 71, 74, and 75 (GA I, 6; 257, 260, and 261). So, the consciousness here must be a consciousness that assets itself in action, not knowledge of a logicaldeductive sort.

Fichte then suggests that it is the consciousness of our active agency that can send us beyond mere knowledge, beyond mere representations. ${ }^{12}$ However, this consciousness is not forced upon us but immediately stems from our voluntary decision to confront our active agency and our moral vocation at its face. This decision of the will is then what Fichte calls "belief (Gluabe)."13 It is typically characterized by Fichte as "the voluntary acquiescence in the view that naturally presents itself to us" (VM 71; GA I, 6; 257). In this respect, we can see that the Fichtean belief is connected to the will in the most intimate way. It is a positing of the will that is given through the feeling of the drive to autonomy. Belief, however, is never separated from knowledge, more precisely, from a judgement and motivations. In fact, Fichte says that belief is concerned with a vision of our vocation.

21 It is now clear that among others, freedom and intersubjectivity ${ }^{14}$ are needed for a proper analysis of our action as moral beings. In other words, instead of resorting to pure theory, we have to go beyond mere representations and focus on our self and its action. Because we as subjects are agents, we must consider ourselves as independent, namely, as able to think freely and so to act (ibid.) even if no knowledge can be its own foundation and proof (VM, 71; GA I, 6: 257). Where then does this agency take us? It not only gives rise to confidence in our own being as a self and in a real world in which we 
can act, but agency also implies free choice, and free choice brings with it the question of which acts we ought to perform. Then the question of constraints and duty naturally arise for us. ${ }^{15}$

For Fichte, then, theoretical philosophy cannot justify its own fundamental principle, which must be grounded on a practical belief that is not knowledge "but a decision of the will to recognize the validity of knowledge" (VM, 70-73, 76, 79, and 97; GA I, 6, 256$59,262,264-65$, and 283). It is not mere knowledge but belief that can allow for the validity of knowledge. Our life as a whole depends on belief, "not knowledge, but a decision of the will to admit the validity of knowledge." (VM, 71; GA I, 6: 257). No "knowledge can be its own foundation and proof," because belief "first gives approval to knowledge," and so "every supposed truth, which is to be produced by mere thinking without having its roots in belief, will surely be false and fallacious." (VM 71-72; GA I, 6: 257-58).

In this way, transcendental reflection leads us to an objective world. But as there are two modes of agency, i.e., physical agency and moral agency, the objective world must be thought of as divided into two different spheres, the sphere of the sensible world corresponding to our claim to physical agency, and the sphere of the supersensible world corresponding to our moral agency. ${ }^{16}$ Because we are physical agents, we can confront the real world in which that agency is effective. But we are also moral agents and, accordingly, we must also confront a morally ordered world in which one's ethical intentions are similarly effective.

We must now transition from the empirical knowledge of material determinism and then from theoretical transcendental idealism to practical transcendental idealism. This also means a transition to the immediate consciousness of self-sufficient freedom. According to Fichte, the moral law requires that the moral subject obey the law without any incentive other than respect for morality. It follows that moral willing is the only goal of the moral subject's activity; but since all our knowledge is discursive, the moral subject must think about the act of moral willing as one member in a series of events, which is connected to a final end by an ordering principle. ${ }^{17}$

It follows that ultimately all knowledge claims depend on practical motives and beliefs, which are "more and higher than all knowledge." As Fichte himself puts it,

This voice [within me] leads me outside of mental representations, out of mere knowledge, to something which ... is more and higher than all knowledge and contains the final purpose of knowledge itself within it. (VM 68; GA I, 6: 254)

This difference between belief and knowledge is "no mere verbal distinction but a true deeply founded distinction of the most important consequence." It follows that the practical transcendental idealism that is suitable to our "dignity and vocation" is far from being nihilistic. Because he recognizes that believing involves a volutary acceptance of knowledge (and that knowing involves a free acceptance of belief), which he chooses not because he "must" but because he "wants" to, he apprehends that transcendental idealism is not fatalistic, as F. Jacobi charges. As Fichte puts it,

[I]t is not these [empty images of things supposedly existing outside ourselves] but the necessary belief in our freedom and strength, in the reality of our acting ... that justifies all consciousness of a reality existing outside of us-a consciousness which itself is only a belief since it is based on belief, but a belief that necessarily follows from consciousness (VM, 79; GA I,6: 264). 
The Fichtean 'belief' is none other than our moral consciousness because the moral law requires the moral subject to obey without disturbing another moral subject's freedom, so the moral subject cannot intend to influence others against their will. In this way we can see that it is not empirical knowledge but transcendental act of will that justifies the fundamental principles of discursive knowledge, which is necessary for life. The purpose of life, and so the "final purpose of knowledge," is moral activity (VM, 64-65 and 67-68; GA I, 6, 251-52 and 253-54). Thus, Fichte can be seen here deploying a transcendental argument, based on the Kantian presupposition that purposive behavior or agency is not the mere production of natural causal necessity, but aims at efficacy in a purely rational order-or the cultivation of will for sake of will. Drive, interest, and purpose are all gradations of rational activity that culminate in morality. of this Fichte emphatically claims:

This voluntary acquiescence in the view [that] naturally presents itself to us, because only on this view can we fulfill our vocation, ... first gives approval to knowledge and raises to certainty and conviction what without it would be mere deception. ... All my conviction is only belief; and it proceeds from my disposition. (VM, 71 (GA I/6, 257). ${ }^{18}$

Furthermore, the Fichtean belief carries the sense of prudential belief in the efficacy of rational action creating not only a better, but a utopian world: "[T] hat purpose has got to be achieved. Oh, it is achievable in life and through life, for reason commands me to live. It is achievable, for-I am" (VM, 91; BM, 276).

Earlier, in the System of Ethics, conscience (Gewissen) is also offered as the further condition of the possibility of our practical, moral belief (SE IV 147). Here Fichte argues that conscience is "the immediate consciousness of that without which there is no consciousness: the consciousness of our higher nature and of our absolute freedom" (ibid). And this typically takes the form of hearing the voice within ourselves. Conscience, Fichte tells us, is concerned with "our consciousness of our determinate duties" (SE IV: 173), and it produces a "conviction (überzeugung)" accompanied by the subjective feeling of "certainty (Gewissheit)." 19 Indeed, for Fichte, to lead a moral life means to act with consciousness of duty. Thus, morality demands that we make sure to ascertain for ourselves what our duty is (SE IV 153, 163). Thus, to act from duty requires our conviction or belief concerning our duty.

Once we are clearly convinced of our determinate duties, we cannot act against them (SE IV:191). When we are convinced about duty, it is wrong not to act in accordance with it. We would be immoral when we obscure and neglect our consciousness of duty (SE IV: 192).

31 Consequently, our moral/practical belief involves an employment of various mental faculties including the original (or ethical) drive, the immediate feeling of conscience (that never errs) and the reflecting power of judgment (that can err). ${ }^{20}$ As an individual moral agent, I must examine what my duty is by way of deliberations about my actual life situation, my current beliefs and other agents' views. When I carry this out, I then get the objective conviction about my duty, which is then accompanied by a subjective feeling of certainty. So, when I hear the deliverances of my conscience, I have "the feeling of certainty that there is a compete harmony of my empirical I with the pure I" (SE IV: 169). Conscience for Fichte then is the power of feeling that plays a critical role in securing moral belief. ${ }^{21}$ Fichte claims: 
For the sake of conscience, every human being must judge for himself and must compare his judgment to his own feeling: otherwise he acts immorally and unconscionably (SE IV: 168, 176). is to say, we are brought to confront just who we are. By means of conscience, then we become acquainted with ourselves in action. "Only," as Fichte puts it, "through [...] commandments of conscience do truth and reality come into my representations. I cannot refuse them my attention and my obedience without giving up my vocation" (VM 76; GA I, 6: 261). Conscience then expresses the very relation of oneself as a practical agent through which one comes to grips with one's own true nature, not only as mere theoretical reason, that is to say, as cognizer of reality and consciousness, but also and primarily as something that has to be realized in this world through one's acting. In this respect, we are only certain of our own ability and possibility to act through conscience and through our "conception of a moral world" (VM 78; GA I, 6: 264). In other words, conscience entails a special kind of self-relation through which we are acquainted with ourselves and our existence, especially since our knowledge of acting is something about which we are, as Fichte explicitly states, "immediately certain" (VM 79; GA I, 6: 265). Whereas theoretical knowledge can be doubted, knowledge of our own ability to be moral and, therefore, of our own being, cannot be doubted. Of this, Fichte has this to say: "We raise ourselves out of this nothingness and maintain ourselves above this nothingness only through our morality" (ibid.)

At a critical juncture in the third section of the Vocation of Man, Fichte now boldly declares: "Conscience alone is the root of all truth," or alternatively, "truth," as Fichte puts it, "has its origin in conscience alone" (VM 72; GA I, 6: 268). For it is an absolute presupposition that - in the moment of a drive to act - we must believe that our drive is eo ipso our drive (i.e.., it is me who acts) and that it is the right and thus, "true," drive. Consequently, according to Fichte, conviction or belief is the necessary condition of a "truth" that is established beyond the distinction between right and wrong, for it constitutes our own consciousness in the moment of action and self-activity. This is to say, it constitutes the truth of ourselves..$^{22}$ Put differently, belief creates a basic truth and absolute certainty of a decision in the very moment of the decision, which at this very moment can no longer be "conceived" as wrong, that is, as something that does not belong to the agent. As Fichte puts it,

Nor can I refuse to believe in the reality which [the commandments of conscience] bring along without likewise denying my vocation. It is simply true, without further testing and justification, it is the first truth and the ground of all other truth and certainty, that I ought to obey that voice (VM 73; GA I, 6: 261, emphasis mine)

Because of our active nature, we have a goal, a vocation in life. In other words, we are ineluctably and irreducibly active beings and this immediately implies a moral universe. Why would moral obligations tell us that there is a real world? The point is that the real power of human beings lies in action. At the conceptual climax of The Vocation of Man, Fichte suggests that by anchoring his entire system properly on a firm foundation in 'belief,' can he finally dispose of the genuine threat of nihilism and solipsism. This 'belief involves metaphysical commitment to the reality of a supersensible world populated exclusively by active intelligences. ${ }^{23}$ Fichte's implication here is that the system in question concerns belief in our agency and in a realm of external objects in which that agency is efficacious. Our entire life - not just theoretical life but also practical life - then rests on belief.

Revista de Estud(i)os sobre Fichte, 17 | 2018 
Already two years earlier in "On the Ground of Our Belief in a Divine Government of the Universe" (1798), Fichte suggests that "our conviction concerning our own moral determination or vocation is itself already the result of a moral disposition and is a matter of belief" and goes on to claim that "belief is the element of all certainty" (147; GA I,4: 351). Later, he also adamantly insists that "your vocation is not merely to know but to act according to your knowledge" (VM 67; GA I, 6: 253).

What then is the content of the commitment shown by the Fichtean belief or for that matter conscience? What is the belief a belief in? First of all, there is no question it refers to our deepest commitment to and reaffirmation of our nature as pure activity. As Fichte puts it, "what grounds all consciousness of a reality outside ourselves is the necessary belief in our freedom and power to act, in our actual acting and in the determinate laws of human acting. Such consciousness is itself only a belief, since it is grounded on a belief [in our own acting], but it is a belief that necessarily follows from the latter belief (VM 79; GA I/6, 265). In this sense, the (necessary) belief is clearly different from discursive or logico-deductive knowledge. For the former has something to do with "a decision of the will" to admit the validity of knowledge. Belief then implies a "firmness of my confidence," that is "reason's firm and unshakable adherence to a principle" (VM 104; GA I, 6: 290).

For Fichte, belief also serves as a type of non-theoretical knowledge within his search for an alternative conception of the self. It then expresses an immediate intuition of the self whose nature is not fixed but in constant, dynamic operation. But this also implies that we must believe in the reality of other finite rational beings and the sensible world as well as the supersensible world, the last of which must include its governing law which Fichte calls "One Infinite Will" (VM 105-107; GA, I/6 291-3).

Methodologically, Fichte's practical transcendental idealism purports to give an account for all experience strictly in terms of subjective states and autonomous intellectual activities. As Fichte puts it,

[T] he consciousness of a thing outside of us is absolutely nothing more than the product of our own representational capacity.... in what we call knowledge and observation of things we always and ever only know and observe ourselves, and ...in all our consciousness we simply know of nothing other than ourselves and our own determinations. (VM 59; GA I, 6: 246-47)

This is also the point that he made clear when he said that "everything which occurs in our mind can be completely explained and comprehended on the basis of the mind itself" early in his career in his "Review of Aenesidemus" (EPW, 69; GA I, 1; 15). ${ }^{24}$

40 So, belief directly discovers the reality of meaning, purpose, and value (in the form of the normativity of norms and of the efficacy of purposes). But belief also indirectly reveals the reality of freedom and of 'providence.' This of course means that mechanism and nihilism is false. For on then can norms be genuinely binding, and purposes efficacious. Dogmatic Spinozism only leads to mechanism and determinism. Indeed, in the essay "On the Ground of Our Belief in a Divine Government of the Universe," he also suggests that the "belief must be seen as the core element of a religion that is based in reason alone," especially since, as Fichte puts it, the "true belief" in the moral world order "is constituted by right action." ${ }^{25}$

But belief in this peculiar Fichtean sense has another aspect as well- the teleological aspect. As we have learned so far, "belief" refers to the certainty of the actuality of our own self. However, since belief in our morality and conscience establishes the 
possibility of actions and decisions, we must take the ends of our action and their means to them into account. As Fichte puts it, "can I will, without having something which I will? No:--this would entirely contradict the nature of my mind" (VM 79; GA I, 6: 265). I am simply to act but if this is the case, then something resulting from this activity must necessarily become a "purpose" for me. For "I ought to carry out the act which is the means to this purpose and only to it" (VM 80; GA I, 6: 266). This, however, does not meant that for Fichte purposes here should drive 'the ought.' Purposes should not drive the will. Rather, the active will 'ought' to create the purpose. It is a short step here to infer that "to every action there is united in my thought, immediately and by the laws of thought itself, a condition of things placed in futurity, to which my action is related as the efficient cause to the effect produced." Accordingly, "the end does not determine the commandment; but, on the contrary, the primitive purport of the commandment determines the end" (VM 80; GA I, 6: 265) All my thoughts must have a bearing on my actions, and must be capable of being considered as means, however remote, to this end, and "as I live in obedience to it [viz. conscience, or belief], I live also in the intuition of its purpose; live in the better world which it promises to me" (VM 80-81; GA I, 6: 266).

As pointed out earlier, the Fichtean belief clearly does not express ordinary discursive knowledge as it involves a "decision of the will to recognize the validity of knowledge" (VM 71; GA I, 6: 257). Indeed, it is a "voluntary acquiescence in the view which naturally presents itself to us because only on this view can we fulfill our vocation" (Ibid.) However, note this does not mean that belief is arbitrary, imposed, or irrational. It is an activity of reason, albeit without any involvement of such operations as reflection, abstraction or comparison. ${ }^{26}$ Following this claim, Fichte also suggests that belief can even quickly turn into "[...] good will [...]" and conscience (which, by the way, are moral/practical concerns) (VM 72; GA I, 6: 258). In a word, "we are all born in belief" (VM 73; GA I, 6: 259). We don't have to blindly act in accordance to a naturalistic/ materialist hard determinism, if we are, in fact, free, as posited by Fichte. Our 'vocation' is that we can act in accordance to our will, rather than, by nature (Ibid.).

This view of belief on the part of Fichte, however, is not an aberration in his system nor a return to a pre-critical dogmatism but consistent with Fichte's transcendental project. In particular, the Fichtean 'belief' is not a retraction of the transcendentalepistemological approach to explaining experience. ${ }^{27}$ "The world," as Fichte puts it in "Our Belief in a Divine Governance," is "nothing more than our own inner acting (qua pure intellect), made visible to the senses in accordance with comprehensible laws of reason and limited by incomprehensible boundaries within which we simply find ourselves to be confined (EPW 149, G/A I,4: 353) [i.e., unchosen empirical givens]. Fichte thus continues:

Granted, the origin of these boundaries is incomprehensible; but, replies practical philosophy.... [n]othing is clearer or more certain than the meaning of these boundaries: They constitute your determinate place in the moral order of things. ("Our Belief in a Divine Governance," ibid.)

In an important suggestion, Stephen Hoeltzel argues that the Fichtean 'belief' is subject to critical control by the transcendental-epistemological explanation of experience. Fichte accordingly holds that we posit nothing of a kind not proven to exist by the aforementioned explanation. We have no reason to believe in any other kinds of things. ${ }^{28}$ As Fichte claims, 
free spirits alone are real ... an independent, sensible world through which they might act upon each other is quite unthinkable. (VM 109; GA I, 6: 294) 's 'first principles,' which articulate the ultimate conditions of the possibility of experience) ${ }^{30}$ For 'belief' undertakes to capture the primordially projectival nature of the transcendental subject (the finite rational being). In this respect, belief involves an essential commitment to the total rational comprehension and moral perfection of all that it experiences. Here is what Fichte has to say:

The whole final purpose of reason is its own pure activity.... (VM 99; GA I, 6: 284)

47 A full metaphysical commitment is thus offered by 'belief' and the transcendental subject exists in relation to something other than itself, i.e., a 'higher' order of being that its sensory states somehow signify, and that its autonomous endeavors can advance or enhance. As Fichte puts it,

If I am to be able to recognize that obedience as ration, if it really is to be reason which forms my being, and not an extravagant fancy of own invention or dragged in from somewhere or other ... then this obedience [to the imperative of autonomous activity] must have some outcome or serve some purpose. Evidently it does not serve the purpose of the natural earthly world. There must, therefore, be a supernatural world whose purpose it serves. (VM 93; GA I, 6: 278)

'Belief' for Fichte then constitutes an irreducible and unobjectionable practical postulation. This is no theoretical proof-no epistemic norms obligate anyone to adopt this view of things. According to Fichte's transcendental idealism, then the ultimate ethical norm does thus obligate us and norm has as much authority over the rational being as do any and all principles of theoretical rationality.

Note that this metaphysical commitment cannot be justified on epistemic grounds, as shown by the discussions so far, but can be vindicated on ethical grounds. In this regard, he inherits the strategy from Kant as the latter is committed to the objective but practical reality of God and other supersensible entities on ethical grounds. This means that for Fichte's project, ethical norms are no less authoritative for rational beings than are epistemic ones.

While 'belief' falls far short of the basic requirements for rational discursive, logicaldeductive knowledge, it remains in perfect accord with the ultimate requirements of reason (considered in its purest and most radical forms). In this respect, belief may be equated with intellectual intuition. Faith establishes what Fichte calls the "harmony of all external things with his [man's] own necessary, practical concepts of them," which is the "total self-harmony or absolute identity." It can be realized through the will in fulfilling the final end of man's perfection. ${ }^{31}$

51 Fichte also points out that Knowledge produced without belief "is surely false and fallacious, since bare and pure knowledge ... leads only to the insight that we can know 
nothing. ... I know that such false knowledge never can discover anything other than what by faith it has first put into its premises... " (VM 72; GA I, 6: 258). In a passage that sounds almost paradoxical, Fichte claims that "we do not act because we know, but we know because we are meant to act. Practical reason is the root of all reason" (VM 79: GA I, 6: 265).

In this way, we are able to construct our view of world with the immediate consciousness of ourselves, through our certainty about our conscience and our moral vocation. The vision that Fichte has about the entire world does not leave room for any theoretical or conceptual explanation of the creation of this self-certainty. This is because every explanation is tied back to theoretical reason, but - instead - we will find an element in our consciousness that allows us to see while we are acting.

\section{Kant and Fichte}

From what we have observed, it is clear that Kant and Fichte are united in holding that belief in the practical sense is more important than epistemic knowledge. Further, this importantly stems from their common view that practical reason is more important than theoretical reason. How then is the Fichtean belief different from the Kantian postulates? The motivation for Kant's theory of postulates, as we have seen, stems partly from Kant's stake in the pantheism controversy, as well as from his architectonic conception of philosophy, which culminates in his doctrine of the primacy of practical reason over theoretical reason. However, Kant never claims that theoretical reason originates from practical reason. He merely claims that the claims of practical reason take precedents over those of theoretical reason.

On the other hand, Fichte's motivation stems importantly from the ultimate goal of establishing the Wissenschaftslehre on the firm foundation of the self's pure activity. While Fichte's belief is different from speculative/dogmatic flight of fancy, there is no denying that what conscience - as our inner voice - delivers, i.e., a conviction, is immediately intuitive, infallible and certain as far as Fichte is concerned. But the Kantian postulates are not of this nature. It may take an 'existential' leap of faith to accept the Kantian postulates but they definitely require heavy rational backing from moral considerations. It is also obvious that Fichtean the feeling of conscience cannot be doubted ("conscience never errs"!) at least its formal aspect is concerned. However, Kantian Glauben may be doubted, it seems.

55 Further, the Fichtean belief is not propositional while the Kantian Glauben are propositional. In other words, the Fichtean belief is not discursive whereas the Kantian Glauben are discursive, albeit the latter are "theoretical propositions" inextricably bound up with practical cognition. We can also point out that the Fichtean belief is not reflexive. Finally, the Fichtean belief is voluntary yet intellectual. At least the Fichtean belief about self's active nature seems to involve intellectual intuition. The Kantian Glauben are composed of the Ideas of reason and have nothing to do with intellectual intuition. However, Fichte suggests that, while our belief about our own nature is immediately certain, our belief about the external world of sense, etc. is not immediately certain and the latter's certainty must be derived from the former.

The most radical difference between the two, however, seems to be that belief is the source of our knowledge of the world on the part of Fichte, but not Kant. For the former, as Zöller puts it, "freedom and its laws have original certainty and epistemic 
authority for theoretical knowledge claims." 32 After all, for Fichte, "practical reason is the root of all reason" (VM 98: GA I/6, 265). Beginning with the self, Fichte, on the sole basis of the beliefs, goes on to prove the existence of the material body which is the substantial agent of the self's action, and the non-self or external material world, which is the object of its actions, and also other selves by way of summons. The Kantian Glauben are not the source of the knowledge at all. The latter are merely compatible with the scientific knowledge of the natural world. Conscience/belief is the source of knowledge of the world, at least when formally considered, because it gives rise to the discursive knowledge by forming the latter's condition of possibility. The Kantian Glauben, however, can be made compatible with and can be harmonized with the knowledge of the world. Finally, the Fichtean subject first acts before doing anything else. The Kantian subject performs the act of self-consciousness first as the transcendental apperception so it is primarily theoretical-conceptual. The Kantian subject is also premised on the distinction between the appearances and the things in themselves while the Fichtean subject knows no such distinction-the whole world is nothing more than the manifestation of the inner acting of the self, albeit Book III of the Vocation of Man also ventures out to suggest that what is now considered to be the proper domain of legitimate philosophical inquiry has expanded considerably since 1794, inasmuch as it now embraces the entire supersensible world, understood as existing on its own, apart from the finite human mind, as well as the independently existing author of the same: "the One, which exists ... the original source [Urquelle] of both you and me"(VM, 107; GA, I/6: 293). ${ }^{33}$

\section{References}

\section{Primary}

A/B = Kant, Critique of Pure Reason, trans. and ed. Paul Guyer and Allen W. Wood (Cambridge: Cambridge University Press, 1998);

$\mathrm{AA}=$ Kant, Kants gesammelte Schriften, 29 vols., ed. Preussische Akademie der Wissenschaften (Berlin: de Gruyter, 1900- );

CPrR = Kant, Critique of Practical Reason, in Practical Philosophy, trans. and ed. Mary J. Gregor (Cambridge: Cambridge University Press, 1996);

$\mathrm{EPW}=$ Fichte, Early Philosophical Writings, trans. Daniel Breazeale (Ithaca: Cornell University Press, 1988);

FNR = Fichte, Foundations of Natural Right, trans. Michael Baur, ed. Frederick Neuhouser (Cambridge: Cambridge University Press, 2000).

G = Kant, Groundwork of the Metaphysics of Morals, in Practical Philosophy, trans. and ed. Mary J. Gregor (Cambridge: Cambridge University Press, 1996).

GA = Fichte, J. G. Fichte - Gesamtausgabe der Bayerischen Akademie der Wissenschaften, 42 vols., ed. Reinhard Lauth et al. (Stuttgart-Bad Cannstatt: Frommann-Holzboog, 1962- ).

$\mathrm{IWL}=$ Fichte, Introductions to the Wissenschaftslehre and Other Writings, trans. and ed. Daniel Breazeale (Indianapolis: Hackett, 1994).

LM = Kant, Lectures on Metaphysics, trans. and ed. Karl Ameriks and Steve Naragon (Cambridge: Cambridge University Press, 1997). 
$\mathrm{MM}=$ Kant, Metaphysics of Morals, in Practical Philosophy, trans. and ed. Mary J. Gregor, 363-602 (Cambridge: Cambridge University Press, 1996).

NM = Fichte, Foundations of Transcendental Philosophy: (Wissenschaftslehre) nova methodo, trans. Daniel Breazeale (Ithaca: Cornell University Press, 1992).

$\mathrm{SE}=$ Fichte, System of Ethics, trans. and ed. Daniel Breazeale and Günter Zöller (Cambridge: Cambridge University Press, 2005).

SK = Fichte, Science of Knowledge, trans. Peter Heath and John Lachs (New York: Appleton-Century-Crofts, 1970).

VM = Fichte, Vocation of Man, trans. Peter Preuss (Indianapolis: Hackett, 1987)

MPW = Friedrich Heinrich Jacobi, Main Philosophical Writings and the Novel Allwill, trans. and ed. George di Giovanni (Montreal: McGill-Queen's University Press, 2009).

As is standard, with Kant's works I cite the volume and page number(s) of the Royal Prussian Academy edition (AA), which are included in the margins of the translations. With Fichte references, I cite both the English translation (where applicable) and the original German as collected in GA.

\section{Secondary}

Beiser, Frederick. The Fate of Reason: German Philosophy from Kant to Fichte (Cambridge, Massachusetts: Harvard University Press, 1987)

Breazeale, Dainel. "Jumping the Transcendental Shark: Fichte's Argument of Belief" in Book III of Die Bestimmung des Menschen and the Transition from the Earlier to the Later Wissenschafslehre" in Daniel Breazeale and Tom Rockmore, eds. Fichte's Vocation of Man: New Interpretive and Critical Essays (SUNY Press, 2013).

Chignell, A., (2007) “Belief in Kant”, Philosophical Review, 116 (3), 323-360.

Hanna, R. (2013) “Judging, Believing, and Scientific Knowing” (supplement to Kant's Theory of Judgment) Stanford Encyclopedia of Philosophy, accessed on Sept 25, 2017.

Ivaldo, Marco. "Faith and Knowledge and Vocation of Man: A Comparison of Hegel and Fichte ," in Daniel Breazeale and Tom Rockmore, eds. Fichte's Vocation of Man: New Interpretive and Critical Essays (SUNY Press, 2013).

Gottlieb, Michah. Faith and Freedom: Moses Mendelssohn's Theological-Political Thought (Oxford University Press, 2011).

9 Hoeltzel, Steven. Transcendental Inquiry, co-edited with Halla Kim (Palgrave Macmillan, 2016).

80 -_. . "Fichte, Transcendental Ontology, and the Ethics of Belief," in Transcendental Inquiry, ed. Halla Kim and Steven Hoeltzel (Palgrave Macmillan, 2016), 55-82.

-_-. "Transcendental Idealism and Theistic Commitment in Fichte," in The Palgrave Handbook of German Idealism, ed. Matthew C. Altman (Palgrave Macmillan, 2014), 364-85.

_-_. "Non-Epistemic Justification and Practical Postulation in Fichte," in Fichte and Transcendental Philosophy, ed. Daniel Breazeale and Tom Rockmore (Palgrave Macmillan, 2014), 293-313.

--_. Kant, Fichte, and the Legacy of Transcendental Idealism, co-edited with Halla Kim (Lexington Books, 2014). 
84

. "The Unity of Reason in Kant and Fichte," in Kant, Fichte, and the Legacy of Transcendental Idealism, ed. Halla Kim and Steven Hoeltzel (Lexington Books, 2014), 129-52.

Lotz, Christian. “Certainty of Oneself. On Fichte's Conception of Faith as Nonepistemic Self-Consciousness," Southwest Philosophy Review (2004).

Rockmore, Tom. "Traction of the World or Fichte on Practical Reason and the Vocation of Man in Daniel Breazeale and Tom Rockmore, eds. Fichte's Vocation of Man: New Interpretive and Critical Essays (SUNY Press, 2013).

87 Steinberg, Michael. "Knowledge Teaches us Nothing. The Vocation of Man as Textual Initiation in Daniel Breazeale and Tom Rockmore, eds. Fichte's Vocation of Man: New Interpretive and Critical Essays (SUNY Press, 2013).

Wood, Allen. Fichte's Ethical Thought (Oxford, 2016)

Zöller, Günter. Fichte's Transcendental Philosophy (Cambridge, 1998).

\section{NOTES}

1. In his Lectures on Logic (Jäsche Logic, 1801, AA 16:25) Kant discloses the fourth question as is discussed in Anthropology from a Pragmatic Point of View. This sums all of this up and addresses the very nature of a human being.

2. See also Chignell 2007. The last sense of "believing" might be most illuminatingly captured in English as 'believing-in', although the word "Glauben," is sometimes translated as 'faith.' But believing in this sense by no means entails non-rational or even irrational mental states of various kinds.

3. Frederick Beiser, 46.

4. Michah Gottlieb, 81.

5. Steinberg, 57.

6. Dogmatic realism typically holds epistemological foundationalism and assumes that the ordinary discursive knowledge has a foundation in basic knowledge that has direct connection to extra-mental reality. For Fichte, dogmatic realism claims that the non-self (Nicht-Ich) is the cause of representations and that the representations are an effect of the non-self; thus, the non-self is the real ground of everything, and the self (Ich) is a mere accident of the non-self and not a substance at all (Foundations of Entire Wissenschaftslehere (FEW for short), GA I, 2: 310). On the basis of this, he also argued that the very concept of a "thing in itself," understood as a mindindependent, external "cause" of sensations, is indefensible on critical grounds in the Foundations of the Entire Wissenschaftslehre.

7. Fichte acknowledges that neither dogmatism nor idealism could directly disprove each other and thus recognizes that the choice between philosophical starting points could never be resolved on purely theoretical grounds by famously asserting that "the sort of philosophy one chooses depends upon the sort of person one is" (GA I, 4: 195). He nevertheless denies that any dogmatic realism, that is to say, any system that commences with the concept of sheer objectivity, could ever succeed in accomplishing what was required of all philosophy. Dogmatism, he argued, could never provide a transcendental deduction of ordinary 
consciousness, for, in order to accomplish this, it would have to make an illicit leap from the realm of "things" to that of mental events or "representations" (Vorstellungen). Idealism, in contrast, at least when correctly understood as the kind of Critical idealism that demonstrates that the intellect itself must operate in accordance with certain necessary laws, can-at least in principle-accomplish the prescribed task of philosophy and explain our experience of objects ("representations accompanied by a feeling of necessity" (GA I, 4: 187) in terms of the necessary operations of the intellect itself, and thus without having to make an illicit appeal to things in themselves.

8. Cf. "My connection with the whole of nature... determines all I was, all I am, and all I will be.... Whatever I am and become I am and become necessarily, and it is impossible for me to be anything else (VM, 14; GA I, 6: 201).... "I don't act at all but nature acts in me.... Nature makes me and whatever I become." (VM, 19; GA I, 6: 207)

9. The Fichtean term, "Glauben," is sometimes translated as "faith" but this translation can be misleading if faith here implies non-rational or even irrational mental states of various kinds. Further, pace Jacobi's trenchant protest, the Fichtean Glauben is natural, not supernatural.

10. Even in FEW, Fichte suggest that "reality is possible for the self, as well as for the non-self only by means of a relation to feeling. ... With respect to reality as such-that of the self and of the non-self-there is only a feeling" (GA, I/2, 429).

11. Marco Ivaldo, 280.

12. Rockmore, 150

13. In the Second Introduction, Fichte says that "it is only through the medium of the moral law that I catch a glimpse of myself" and goes on to claim that "I necessarily view myself as spontaneously self- active" (GA I, 4: 219).

14. Fichte's notion of intersubjectivity is most perspicuously developed under the idea of summons (Aufforerung) as part of his theory of recognition (Annerkennung) In the Foundations of Natural Right.

15. Steinberg, 62 .

16. Steinberg, 66 .

17. Yolanda Estes, 91

18. See also, VM 75; GA I,6: 261. Compare "Divine World Governance," GA I/5, 354.

19. Conviction here must be based on a practical reasoning that a power of judgment engages in. This judgment then is followed and confirmed by the feeling of harmony (SE 4: 166). Thus, the Fichtean conviction or for that matter belief cannot just any subjective opinion (Allen Wood, 166-7).

20. "Some Lectures concerning the Scholar's Vocation," in Early Philosophical Writings, 179 (GA I,3: 61); "On the Basis of Our Belief in a Divine Governance of the World" in Introductions to the Wissensschafteslehre, 147, GA I,4: 351.

21. The latter essentially involves affective and cognitive components, so to speak. I owe this to Kien-how Goh's observation. Wayne Martin raised an interesting question about the phenomenological manifestation of conscience, which might take the form - in the case of a belief that I ought to do X - of an immediate feeling of harmony/disharmony of my cognition of $\mathrm{X}$ with what is demanded by the original (or ethical) drive. When in harmony, the feeling is one of contentment and approval. Otherwise, it's one of annoyance and disapproval. Sometimes, Fichte also puts it in terms being at one with or contradiction with oneself, or agreement of the head (or mind) with the heart. Finally, the peace of the mind ensues when there is the inner harmony between thoughts and convictions $(156,164)$. But, of course, there are many questions that need to be answered as well.

22. Christian Lotz, 30.

23. Hoeltzel, “Non-Epistemic Justification and Practical Postulation in Fichte," 296. 
24. Jacobi characterizes the Fichten belief as: "rational intuition, or the intuition of reason" i.e., direct non-sensory awareness of supersensible realities. Indeed, it is an organ with which we are aware of the supersensible (MPW 540). "Just as there is an intuition of the senses, an intuition through the sense, so there is also a rational intuition through reason ... (MPW 563)" and it "... gives us objects that transcend nature for our cognition, i.e. it makes us certain of their actuality and truth" (MPW 563.) But he most grotesquely misunderstood Fichte when he characterized the latter's view as nihilism that reduced all knowledge and meaning to nothingness in his "Open Letter to Fichte" (GA III, 3: 224-81).

25. Fichte, Introductions to the Wissenschaftslehre, 146: GA I/4, 351.

26. Günter Zöller suggests that belief here expresses the unity of intelligence and volition, head and heart, thinking and willing (Zöller, 124).

27. Hoeltzel, 299.

28. Ibid.

29. For a complete list of Fichte's ontological commitment, see Breazeale, 217.

30. Hoeltzel, 308. The ultimate goal of the Wissenschaftslehre is not to produce knowledge in itself nor analyze it but the intuitive understanding that the self is an activity (Tathandlung), not an object. Indeed, early in the Jena Wissenschaftlehre Fichte made it sufficiently clear that the goal of philosophy is not a mere knowledge but knowledge in the very special sense of the knowledge of knowledge, i.e., foundational knowledge, and how this is possible on the firm basis of the fundamental activity of the self, which knowledge is clearly demarcated from ordinary discursive knowledge

31. "Lectures Concerning the Vocation of Scholars," EPW 150-1; GA I, 4: 299.

32. Zöller, 124.

33. I would like to thank the audience at the North American Fichte Society's biennial conference on Kant and Fichte at Sogang University in Seoul, especially Wayne Martin and Steve Hoeltzel for stimulating questions and discussions. The members of the department of philosophy at the University of Nebraska at Omaha also provided helpful suggestions. Finally, I thank Kienhow Goh for comments on the entire penultimate draft of the paper.

\section{ABSTRACTS}

One of the most venerable distinctions in philosophy is the one between knowledge and belief. Knowledge has been typically associated with genuine or scientific cognition that can provide truth whereas belief has been thought to present mere appearances or subjective opinion, usually founded on sense perceptions. In this paper, I will argue that for both Kant and Fichte, this standard view is mistaken and that they present belief (Glaube) as more important than knowledge. Even though Kant admits that knowledge is prior, and superior, to belief as well as opinion in their purely epistemic dimension, he nevertheless ends up holding that belief in the more significant sense of a 'postulate,' is more important than knowledge. I will also argue that this is the fundamental point of his well-known doctrine of the primacy of practical reason over theoretical reason. The standard view is also challenged by Fichte's thoroughgoing transformation of our epistemic enterprise. According to Fichte, belief (Glaube) is prior to knowledge (Wissen), since it has something to do with "a resolution of the will" to admit the validity of knowledge. Belief here is equated with the practical act of the self that expresses its true nature as Tathandlung. In the course of the paper, I will also show that Kant and Fichte seem 
to argue for their view in a different way. For Kant, the superiority of belief is presented as part of his architectonic concern, i.e., as an answer to the question "what may I hope" in the context of his elaborate theory of postulates. For Fichte, the doctrine is presented as part of his transcendental-ontological project of securing the reality of the self and the world from our moral vocation.

INDEX

Keywords: Kant, Fichte, belief, knowledge, postulate

\section{AUTHOR}

HALLA KIM

University of Nebraska Omaha/Sogang University 